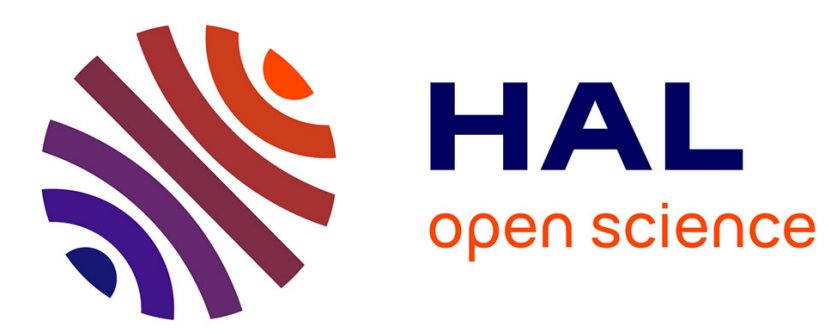

\title{
Behaviour of thermoplastic polymers during explosive decompressions in a petroleum environment
}

\author{
B. Dewimille, J. Martin, J. Jarrin
}

\section{To cite this version:}

B. Dewimille, J. Martin, J. Jarrin. Behaviour of thermoplastic polymers during explosive decompressions in a petroleum environment. Journal de Physique IV Proceedings, 1993, 03 (C7), pp.C7-1559C7-1564. 10.1051/jp4:19937243 . jpa-00251881

\section{HAL Id: jpa-00251881 https://hal.science/jpa-00251881}

Submitted on 1 Jan 1993

HAL is a multi-disciplinary open access archive for the deposit and dissemination of scientific research documents, whether they are published or not. The documents may come from teaching and research institutions in France or abroad, or from public or private research centers.
L'archive ouverte pluridisciplinaire HAL, est destinée au dépôt et à la diffusion de documents scientifiques de niveau recherche, publiés ou non, émanant des établissements d'enseignement et de recherche français ou étrangers, des laboratoires publics ou privés. 


\title{
Behaviour of thermoplastic polymers during explosive decompressions in a petroleum environment
}

\author{
B. DEWIMILLE, J. MARTIN and J. JARRIN
}

Institut Français du Pétrole, Division Chimie Appliquée, Polymères et Matériaux, Avenue de Bois Préau, BP. 311, 92506 Rueil Malmaison cedex, France

\begin{abstract}
Thermoplastic polymers are used in the field of petroleum where they may encounter very severe conditions. So we are induced to study the ageing behaviour and the effect of rapid decompressions in a gaseous environment. In the latter case our aim is to define the limits of use and to identify the parameters influencing degradations. Such damaging is essentially of two types : (1) local in the form of blisters and (2) under extreme conditions, more homogeneous microscopic damage of the "foaming" type. Damage of the blistering type may threaten the integrity of the polymer part, and the microscopic damage does not necessarily affect the mechanical behaviour, for example the impact strength.
\end{abstract}

1 INTRODUCTION : In the field of petroleum, polymer materials may be placed under very severe conditions (contact with liquid and gaseous hydrocarbons at temperatures up to $140^{\circ} \mathrm{C}$, pressures up to 1000 bar or $15000 \mathrm{psi}$ ). Thermoplastic polymers (polyethylenes, polyamides, polyvinylidene fluorides) are used, for example, for sheathing for flexible pipes manufactured by COFLEXIP S.A..

The aspects of ageing, chemical or not, are the subjects of specific research at IFP and we illustrate our methodology and the means of characterisation we use by Figure 1 below.

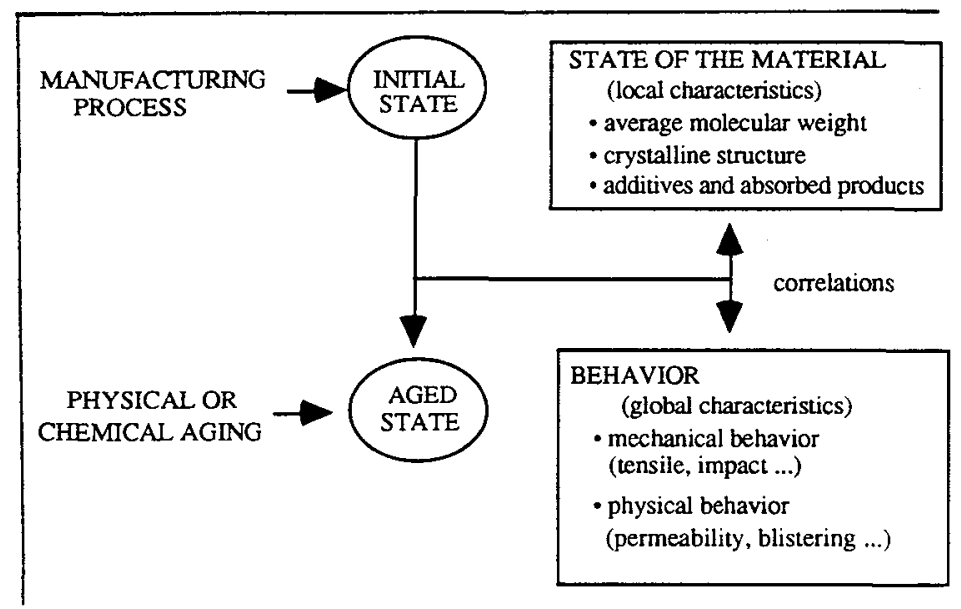

Eigure 1 : Illustration of the methodology to study the behavior of polymeric materials 
Testing methods and procedures thus had to be developed to access and compare materials. But we dwell here on degradation phenomena linked to the presence of gas under high pressure. Gas absorption in a polymer is greatly increased under high temperature and pressure conditions, and variations in these parameters, especially during rapid decompressions, may cause degradations of such materials, called blistering.

\section{METHODOLOGY AND EXPERIMENTAL MEANS}

In the case of degradations induced by fast decompression after gas absorption, the parameters that can be considered as having a major impact are listed below :

- diffusion and solubility (gas transportation and storage in the polymer),

- modulus (rigidity) and toughness (ability of polymer to withstand initiation and propagation of damage),

- geometry (thickness) and presence of defects,

- pressure, temperature, type of gas, decompression rate (parameters related to the medium).

The studies we have been doing in this area have a twofold purpose. The first is to examine the behaviour and operating limits of flexible pipe sheaths. The second is to understand damage mechanisms and the effects or different parameters better.

We have been using a procedure for over 15 years to test materials. Samples are placed alternately in an oil medium and then in a gas medium (one week each) with periodic sudden decompressions. The test is performed at $100 \mathrm{bar}(1500 \mathrm{psi})$ and $100^{\circ} \mathrm{C}$ and can be continued up to one to two years if periodic observation shows no degradation. A second faster procedure has just been developed for testing at much higher pressures (up to 1000 bar, 15000 psi) with a gas such as $\mathrm{CH}_{4}, \mathrm{CO}_{2}$ or $\mathrm{H}_{2} \mathrm{~S}$. A facility with two test cells has been set up in an explosion-proof environment. A suitable compressor provides the desired pressure, which is maintained along with a set temperature for several days. We then proceed with a sudden decrease in pressure. Decompression time can be regulated, with the fastest being a drop of 1000 bar in some seconds. The materials may of course be aged beforehand in other cells, and testing can also be done in the presence of a liquid.

When the samples of materials are removed from the cell after undergoing the test, they are examined, measured and weighed to see to what extent blistering and changes in volume and density have occurred. Further analys are also performed, such as an X-ray scanner run and scanning electron microscope examination after cold fracturing.

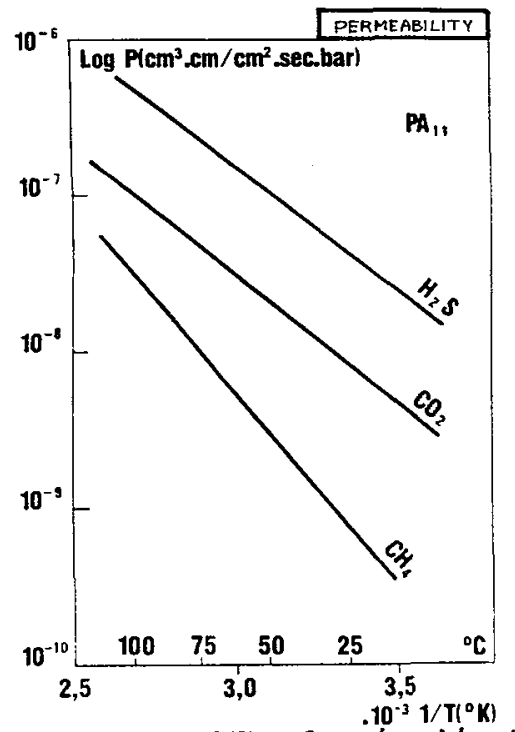

Even though a flexible pipe's inner sheath is called a "leak-proof sheath", it can not be totally gas-tight since it is made of a polymer. The permeability phenomenon is thus quite considerable and was measured on a number of materials as a function of temperature and for different gases as illustrated in Figure (2), (example with a polyamide).

In a first step the measurements were carried out up to about 100 bar (1500 psi), but we are designing a high-pressure testing facility that can reach 1000 bar (15000 psi). In addition, since solubility and diffusivity parameters are so important, particularly in the blistering problems mentioned in the following section, we have automated our measuring instruments to evaluate these parameters during permeability testing.

Eigure 2 : Permeability of a polyamide with different gases 


\section{EFFECTS OF RAPID DECOMPRESSIONS IN A GASEOUS ENVIRONMENT}

\subsection{Degradations observed}

The negative consequences of gas permeability and of blistering for thermoplastic materials are significantly less than for elastomers.

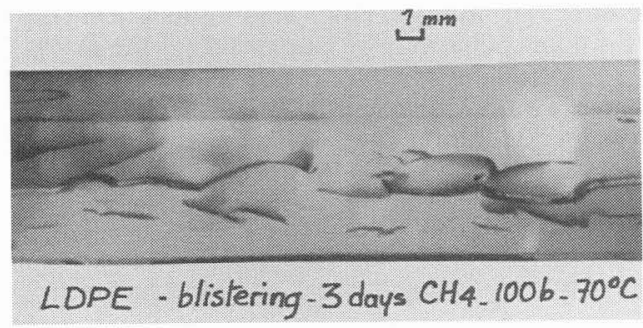

As with elastomers, blisters can be observed (see Figure 3) but under higher pressure or temperature. These are macroscopic damage that must be avoided to maintain the integrity of the structure. But, under more severe conditions and for materials that have sufficiently high toughness to resist to crack propagations (conventional blisters), we have identified micro damage that is visible on the $\mathrm{X}$-ray scanner as a density gradient through the material's thickness (Fig. 4 shows a substantial drop in density of about $30 \%$ in the centre of the sample).

Figure 3 : Example of blisters in a sample of low density polyethylene

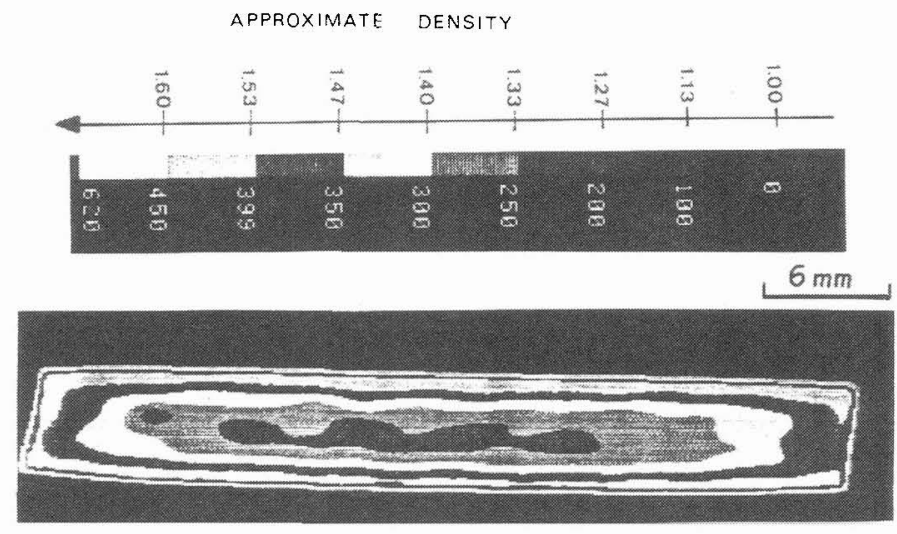

Figure 4 : Density gradient observed on the cross section of a plastic sample by means of $X$-ray scanner apparatus, after a fast decompression $\left(\mathrm{CH}_{4}-1000\right.$ bar $\left.-140^{\circ} \mathrm{C}\right)$

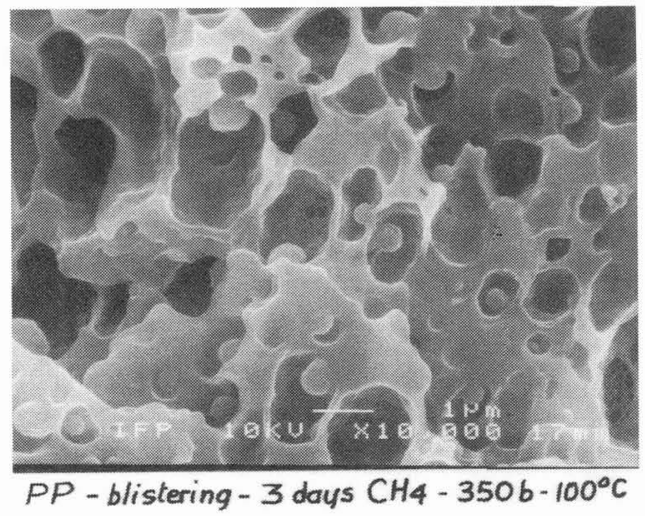

It shows up on the electron scanning microscope as a cellular structure in which the bubbles or empty spaces are around a micrometer in size (Fig. 5). For some polymers we can see damage with a size underneath 0.1 micrometer (Fig. 8).

Sudden expansion of a gas can thus cause either blisters or a foam like structure or both together.

Eigure 5: SEM observation of a polypropylene, after blistering, showing microscopic damages of cellular form. 


\subsection{Limits of Use of Thermoplastics}

Whereas one of the goals of our research is to study degradation mechanisms, so as to understand the conditions for the appearance of damage (as a function of the parameters listed in the preceding section), a more practical goal is to determine the limits of use of various thermoplastics. Criteria must necessarily be used to determine these limits. The first such criteria is the appearance of microscopic blisters (that can be said to be a defect in the material), and the second is the appearance of micro-cavities leading to a decrease in density (or an increase in volume) of more than 4 or $5 \%$. This latter point may be contestable to the extent that the material may still be capable of fulfilling its function (see following section). However, we use these criteria to illustrate, in Figure 6, the differences in behaviours that we find in several polymers as a function of test temperalure and pressure, and for very severe decompression conditions.

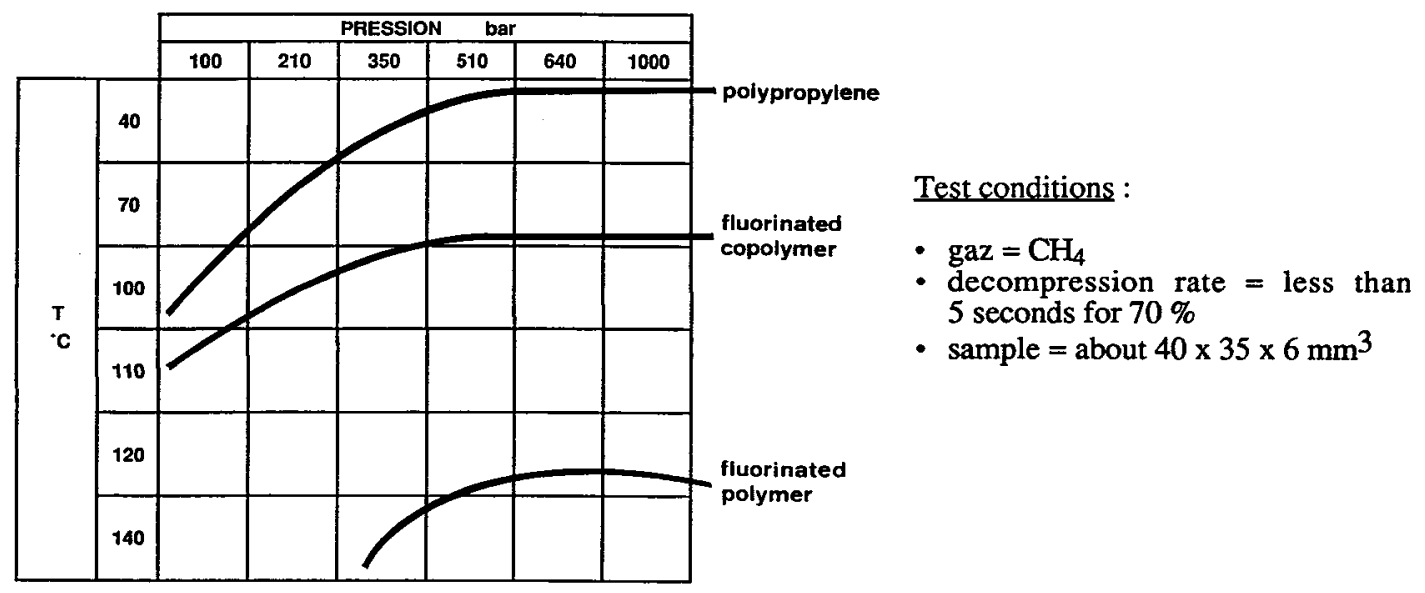

Figure 6: Example of results obtained during fast decompression tests on some plastics. The curve (in the pressure/temperature diagram) describe the limits underneath which we observe either the appearance of blisters or a foaming phenomenon leading to a volume increase above about $5 \%$.

\subsection{Effect of Damage on Mechanical Behaviour}

The appearance of blisters, which are generally cracks several milimeters long, can be considered to be a phenomenon that should preferably be avoided by choosing a material that resists this type of degradation. However, the appearance of micro-damage is difficult to prevent when the material is placed under very severe conditions, such as those induced by our simulation tests. By taking a PVDF (polyvinylidene fluoride) tested under the most severe conditions $\left(140^{\circ} \mathrm{C}, 1000\right.$ bar of $\mathrm{CO} 2,50 \%$ decompression in 2 seconds and 95 $\%$ in 30 seconds), we have tried to show that this material, even when badly micro-damaged, does not have a complete defective mechanical behaviour. 
The photos in Figures 7 and 8 below show that, after the blistering test, we obtain a certain number of cavities of about one $\mu \mathrm{m}$ (Figure 7) and a multitude of much smaller cavities (Figure 8). In the present case, the decrease in density is greater than $30 \%$.

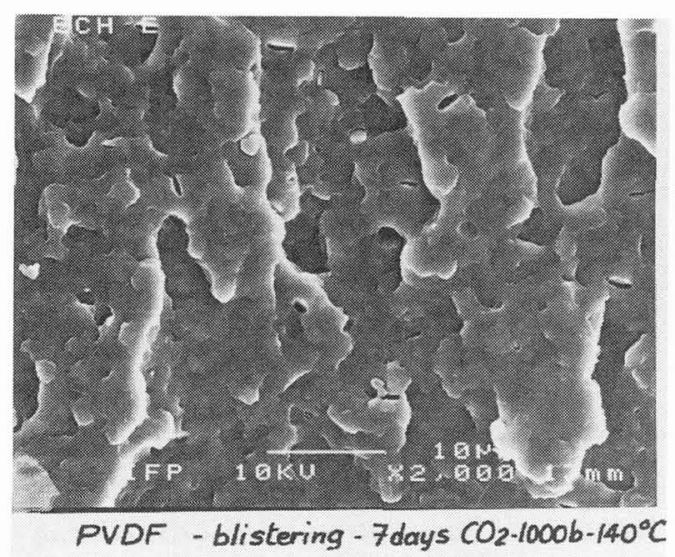

Figure 7: SEM observation of the plastic with visible microdamage of $\mu \mathrm{m}$ in size

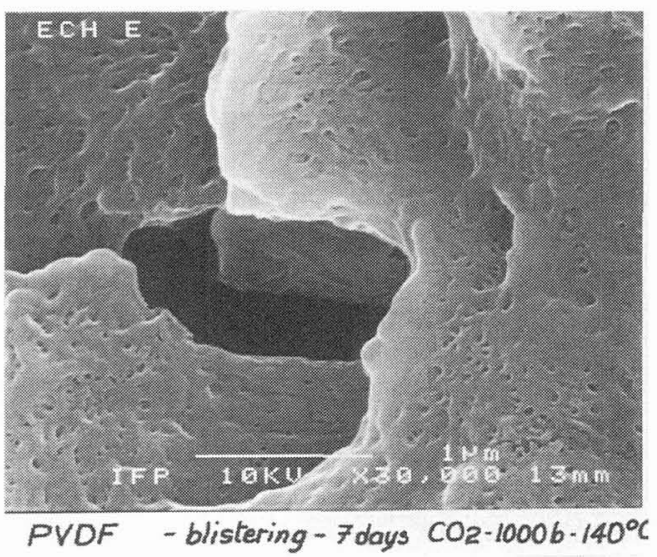

Eigure 8: View at a higher magnification showing a 1 $\mu m$ damage and many others with a size underneath $0.1 \mu \mathrm{m}$

The mechanical behaviour was evaluated by standard tensile tests and by instrumented impact tests. The results obtained are given in Figure 9 and are illustrated by the curves in Figures 10 and 11.

\begin{tabular}{|c|c|c|c|c|c|c|}
\hline & \multicolumn{5}{|c|}{ TENSILE TESTS } & \multirow{3}{*}{\begin{tabular}{|c} 
IMPACT \\
TESTS \\
Energy \\
\\
$\mathrm{KJ} / \mathrm{m}^{2}$ \\
\end{tabular}} \\
\hline & \multirow{2}{*}{$\begin{array}{c}\text { Modulus } \\
\text { E } \\
\text { MPa } \\
\end{array}$} & \multicolumn{2}{|c|}{ Yield Point } & \multicolumn{2}{|c|}{ Rupture } & \\
\hline & & $\begin{array}{c}\sigma y \\
\mathrm{MPa}\end{array}$ & $\begin{array}{c}\boldsymbol{\varepsilon y} \\
\boldsymbol{\%}\end{array}$ & $\begin{array}{c}\sigma_{R} \\
\mathrm{MPa}\end{array}$ & $\underset{\%}{\boldsymbol{\varepsilon}_{\mathrm{R}}}$ & \\
\hline Virgin Material & $\begin{array}{l}1270 \\
\pm 6 \%\end{array}$ & $\begin{array}{c}57 \\
\pm 1 \%\end{array}$ & $\begin{array}{l}10.4 \\
\pm 2 \%\end{array}$ & $\begin{array}{r}45.7 \\
\pm 8 \%\end{array}$ & $\begin{array}{r}28 \\
+17 \% \\
\end{array}$ & $\begin{array}{c}6.7 \\
\pm 4 \%\end{array}$ \\
\hline $\begin{array}{l}3 \text { days in } \mathrm{CO}_{2} 1000 \text { bar } 140^{\circ} \mathrm{C} \\
\text { + decompressions after } 1 \text { and } 3 \\
\text { days }\end{array}$ & $\begin{array}{c}\mathbf{5 6 0} \\
\pm 21 \%\end{array}$ & $\begin{array}{c}28 \\
\pm 1 \%\end{array}$ & $\begin{array}{l}36.9 \\
\pm 8 \%\end{array}$ & $\begin{array}{l}25.4 \\
\pm 4 \%\end{array}$ & $\begin{array}{c}100 \\
\pm 22 \%\end{array}$ & $\begin{array}{r}13.3 \\
\pm 4 \%\end{array}$ \\
\hline $\begin{array}{l}7 \text { days in } \mathrm{CO}_{2} 1000 \text { bar } 140^{\circ} \mathrm{C} \\
\text { + decompressions after } 1,3 \text { and } \\
7 \text { days }\end{array}$ & $\begin{array}{c}670 \\
\pm 20 \%\end{array}$ & $\begin{array}{c}3 \mathbf{3 0} \\
\pm 1 \%\end{array}$ & $\begin{array}{l}36.4 \\
\pm 6 \%\end{array}$ & $\begin{array}{l}27.4 \\
\pm 6 \%\end{array}$ & $\begin{array}{r}\mathbf{8 5} \\
+22 \%\end{array}$ & $\begin{array}{l}12.2 \\
\pm 3 \%\end{array}$ \\
\hline
\end{tabular}

Figure 9: Table showing the evolution of mechanical properties (tensile at $23^{\circ} \mathrm{C}$, impact at $-20^{\circ} \mathrm{C}$ ) after two types of decompression tests (in CO2, 1000 bar, $140^{\circ} \mathrm{C}$ ). The figures 10 and 11 illustrate the behoviors. 


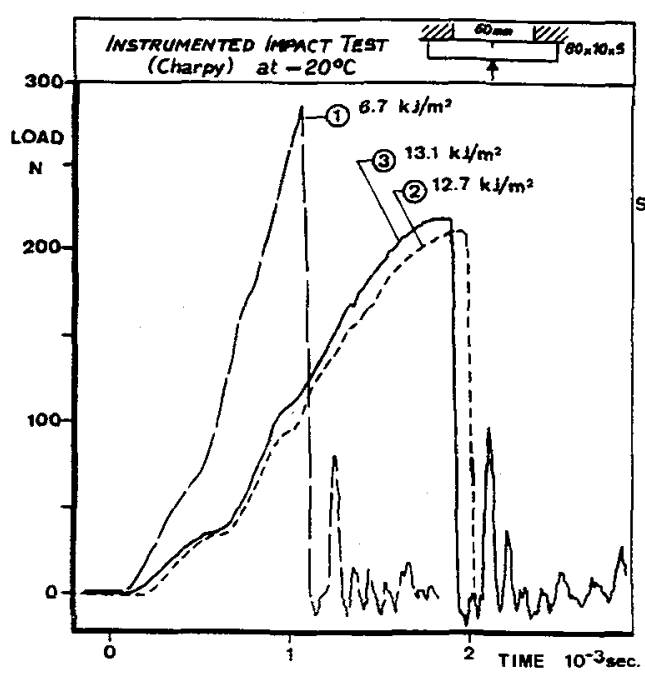

Eigure 10 :Typical impact curves (load versus time) for the tests

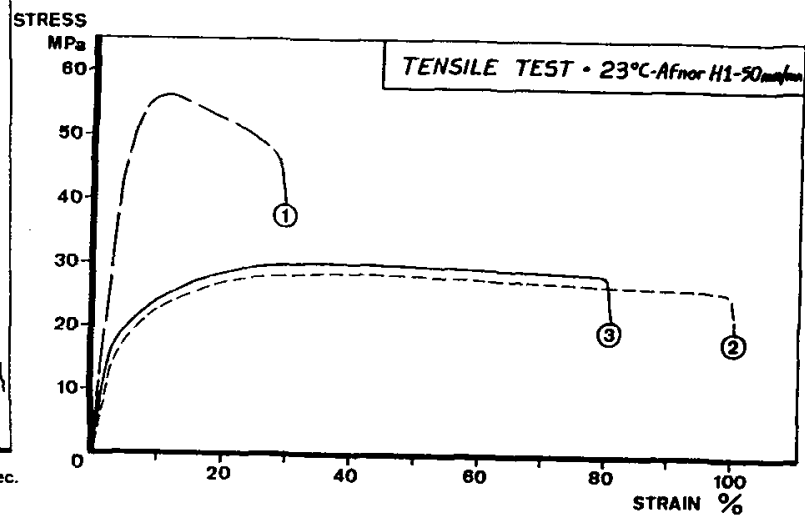

Figure 11 : Typical stress-strain curves during tensile tests

(1)-Dirgine material ( $P V D F)$

(2)-- -3 days in $\mathrm{CO} 2,1000$ bar, $140^{\circ} \mathrm{C}+$ decompressions after 1 and 3 days

(3) -7 days in $\mathrm{CO} 2,1000$ bar, $140^{\circ} \mathrm{C}+$ decompressions after 1,3 and 7 days

We can see that the damaged material has lost its stiffness and that its characteristic stresses (yield and rupture) have dropped. At the same time, however, we note an increase in the ultimate elongation and in the energy absorbed during the impact. The material has thus become more resilient, which canonly be beneficial, certainly since the size of the degradations produced is smaller than the critical size of defect that would be necessary to increase the brittleness.

\section{CONCLUSION}

The conditions of use of thermoplastic polymer materials in the petroleum industry have led to the development of high-pressure experimental methods for analysing their ageing and their resistance in the presence of gas during sudden decompressions.

The different materials used show quite different behaviours, wich limits their ranges of use. Hence, whereas polyolefins are sensitive to blistering phenomena (macroscopic cracks), the performances of polyamides and especially of vinylidene polyfluorides are much better and often show only degradations of the foaming type (with a size in the vicinity of or smaller than one micrometer). Naturally, the strength of polymers under such severe conditions also depends on the test conditions, and in particular on the type of gas used (CO2 or H2S are more dangerous than $\mathrm{CH} 4$ ) and the presence of a fluid (e.g. hydrocarbons), which, with somme materials such as polyolefins, have a plasticising and solvent effect that may displace the range where blistering appears to lower pressures or temperatures.

The research now being done at IFP aims to gain better control of such effects so as to define accuratly the areas of use of each type of material under conditions of stress, and in some cases to formulate materials with improved performances for specific applications. 